\title{
PENGARUH BUDAYA ORGANISASI TERHADAP KINERJA DENGAN LINGKUNGAN KERJA SEBAGAI VARIABEL MODERASI (Pada Karyawan Balai Penelitian Tanaman Pemanis dan Serat Malang)
}

\author{
Cici Firdian \\ Department of Management FEB UMM \\ E-mail: cicifirdiandi@gmail.com
}

\begin{abstract}
The purposes of this research are, first, is to describe culture organization, work environment and employee performance at Balai Peneletian Tanaman Pemanis dan Serat Malang. Second know whether work environment moderating significant impact culture organization of the performance of employees at Balai Peneletian Tanaman Pemanis and Serat Malang. Sample in this research are employees of administration 40 respondents. Technique data collection using interviews, the questionnaire and documentation. Instrument the analysis used in this research using range the scale and Moderated Regression Analysis (MRA). The results of the analysis range scale culture organizations including on the criteria strong, work environment including on the criteria conducive and performance including the high criteria. The results of the analysis MRS said environment moderating significant impact culture organization of the performance of employees Balai Peneletian Tanaman Pemanis and Serat Malang.
\end{abstract}

Keywords: Cultural organization, Work Environment and Employee Performance

\section{PENDAHULUAN}

Sumber daya manusia mempunyai peranan penting baik secara perorangan ataupun kelompok dalam organisasi dan sumber daya manusia merupakan salah satu penggerak utama atas kelancaran jalannya kegiatan usaha, bahkan maju mundurnya perusahaan ditentukan oleh keberadaan sumber daya manusianya. Untuk itu setiap perusahaan perlu memperhatikan dan mengatur keberadaan karyawannya sebagai usaha meningkatkan kinerja yang baik. Apabila individu dalam perusahaan yaitu sumber daya manusianya dapat berjalan efektif maka perusahaan tetap berjalan efektif (Ghoniyah dan Masurip. 2011:119).

Memiliki karyawan dengan tingkat kinerja yang tinggi merupakan keinginan semua perusahaan ataupun organisasi. Salah satu faktor yang mempengaruhi kinerja dari karyawan itu sendiri adalah lingkungan kerja dan budaya organisasi. Lingkungan kerja haruslah sesuai dengan kebutuhan dari karyawan agar karyawan tersebut dapat lebih maksimal dalam menyelesaikan tugas.

Menurut Nitisemito (1992:182) Lingkungan kerja adalah segala sesuatu yang ada disekitar tenaga kerja dan dapat mempengaruhi 
dirinya sendiri dalam menjalankan tugas-tugas yang dibebankan kepadanya. Menurut Nitisemito (1992: 159) lingkungan kerja diukur melalui suasana kerja, hubungan dengan rekan kerja dan fasilitas kerja. Menurut Rivai \& Mulyadi (2012), budaya adalah bagaimana organisasi belajar berhubungan dengan lingkungan yang merupakan penggabungan dari asumsi, perilaku, cerita, mitos, ide lain untuk menentukan apa arti bekerja dalam suatu organisasi. Menurut Rivai \& Mulyadi (2012) budaya organisasi adalah kerangka kerja yang menjadi pedoman tingkah laku sehari-hari dan membuat keputusan untuk karyawan dan mengarahkan tindakan untuk mencapai tujuan organisasi.

Balai Penelitian Tanaman Pemanis dan Serat (Balittas) yang terletak di Jln. Raya Karangploso, 199 Malang merupakan Balai Penelitian yang mempunyai mandat menangani tanaman perkebunan meliputi tanaman pemanis, serat, kapas, yang didirikan pada tahun 1918. Salah satu permasalahan penting yang dihadapi oleh para pimpinan adalah bagaimana dapat meningkatkan kinerja karyawannya sehingga dapat mendukung keberhasilan pencapaian tujuan. Permasalahan peningkatan kinerja erat kaitannya dengan permasalahan bagaimana cara mengembangkan budaya organisasi yang efektif serta bagaimana menciptakan lingkungan kerja yang nyaman dan kondusif, agar karyawan dapat dan mau bekerja optimal sehingga dapat mendukung pencapaian tujuan organisasi.

Fenomena yang terjadi pada karyawan Balai Penelitian Tanaman Pemanis dan Serat, yaitu kurang maksimalnya kinerja karyawan. Hal ini terlihat dengan banyaknya karyawan yang sering tidak memenuhi target pekerjaan. Target pekerjaan yang ingin dicapai Balittas Malang pada Tahun 2015 dapat dilihat pada Tabel 1 berikut:

Tabel 1 Target Pekerjaan Bagian Tata Usaha Balittas Malang Tahun 2015

\begin{tabular}{|c|c|c|c|}
\hline Sasaran Strategis & Target & Realisasi & Capaian (\%) \\
\hline $\begin{array}{l}\text { Menyusun konsep rencana kenaikan gaji, } \\
\text { kenaikam pangkat, pelatihan, mutasi } \\
\text { karyawan sesuai dengan ketentuan yang } \\
\text { berlaku }\end{array}$ & 50 kali & 43 kali & $86 \%$ \\
\hline $\begin{array}{l}\text { Melaksanakan dan mengecek kegiatan } \\
\text { pengelolaan arsip agar mudah dan cepat } \\
\text { ditemukan bila dibutuhkan }\end{array}$ & 30 kali & 27 kali & $90 \%$ \\
\hline $\begin{array}{l}\text { Melaksanakan kegiatan urusan rumah } \\
\text { tangga dalam menata maupun } \\
\text { membersihkan ruangan agar terasa } \\
\text { nyaman dalam bekerja }\end{array}$ & 45 kali & 38 kali & $84 \%$ \\
\hline
\end{tabular}


Tabel 1 menunjukkan bahwa capaian seluruh sasaran pada tahun 2015 belum terlaksana semua dan belum mencapai target yang telah ditetapkan. Hal ini akan menimbulkan ketidakefektifan dan ketidakefisienan seseorang dalam bekerja, dan lebih jauh lagi dapat menurunkan kinerja. Menurunnya kinerja akan berdampak kurang baik bagi perkembangan organisasi sehingga organisasi harus dapat mengatasi masalah yang terjadi agar karyawan dapat meningkatkan kinerja dalam mencapai tujuan yang ditentukan organisasi, serta karyawan harus bisa bekerjasama dengan baik dalam beruapaya mencapai yang diinginkan organisasi.

Dalam penelitian ini, penulis melakukan wawancara kepada karyawan Balittas yang diperoleh informasi bahwa fenomena yang terjadi dalam lingkungan kerja di Balittas adalah hubungan dengan rekan kerja yaitu masih banyak karyawan yang kurang bekerjasama dengan rekan kerja dalam menyelesaiakn pekerjaan sesuai dengan yang telah di tentukan Balittas. Jadi dapat dikatakan lingkungan kerja Balittas tidak sesuai dengan yang diharapkan.

Hal ini menjadi masalah yang menyebabkan kinerja karyawan menurun, dengan adanya masalah dalam lingkungan kerja memberikan ketidaknyamanan bagi karyawan dalam melaksanakan tugas yang berdampak pada target yang diberikan organisasi tidak tercapai. Terciptanya lingkungan kerja yang baik, diharapkan karyawan mempunyai kinerja yang tinggi, sehingga tujuan organisasi dapat tercapai. Permasalahan lain yang timbul berkaitan dengan kinerja karyawan Balittas adalah budaya organisasi. Sejak berdirinya organisasi secara sadar atau tidak, pendiri meletakkan dasar bagi budaya organisasi yang didirikan. Mereka mempunyai suatu visi sebagaimana seharusnya organisasi itu, kemudian visi tersebut diimplementasikan oleh anggota organisasi menjadi perilaku organisasi. Dengan bertumbuhnya organisasi sebagai hasil interaksi organisasi dengan lingkungannya, secara sadar nilai-nilai pokok tertentu mengalami perubahan.

\section{TINJAUAN PUSTAKA}

Menurut Alex S. Nitisemito (2006) lingkungan kerja adalah segala sesuatu yang ada disekitar para pekerja yang dapat mempengaruhi dirinya dalam menjalankan tugas-tugas yang dibebankan. Lingkungan kerja yang baik yaitu apabila karyawan dapat melaksanakan kegiatannya secara maksimal, sehat, aman dan nyaman.

Lingkungan kerja yang kurang baik dapat menuntut karyawan serta waktu yang lebih banyak dan tidak mendukung diperolehnya hasil yang optimal yang diukur melalui: suasana kerja meliputi tempat kerja, fasilitas dan alat bantu pekerjaan, kebersihan, pencahayaan, ketenangan termasuk juga hubungan kerja antara orangorang yang ada ditempat kerja.

Kebersihan lingkungan kerja yaitu dalam setiap perusahaan hendaknya selalu menjaga kebersihan lingkungan disekitar tempat kerja karyawan. Hubungan dengan rekan kerja yaitu hubungan dengan rekan kerja yang harmonis 
dan tanpa ada saling intrik diantara sesama rekan kerja. Tersedianya fasilitas kerja yaitu tersedianya fasilitas kerja yang lengkap, walaupun tidak baru merupakan salah satu penunjang proses dalam bekerja. Keamanan kerja yaitu jaminan terhadap terhadap keamanan selama bekerja akan menimbulkan ketenangan yang akan mendorong semangat kerja untuk lebih giat bekerja, seperti satpam selalu melakukan pengecekan di setiap ruangan guna untuk memastikan keamanan

Menurut Luthans dalam Susanto (2006:11) budaya organisasi adalah norma-norma dan nilai-nilai yang mengarahkan perilaku anggota organisasi. Setiap anggota akan berperilaku sesuai dengan budaya yang akan berlaku agar diterima oleh lingkungannya. Menurut Sarplin dalam Susanto (2006:120) budaya organisasi adalah suatu sistem nilai, kepercayaan dan kebiasaan dengan struktur formalnya untuk menghasilkan norma-norma perilaku organisasi.

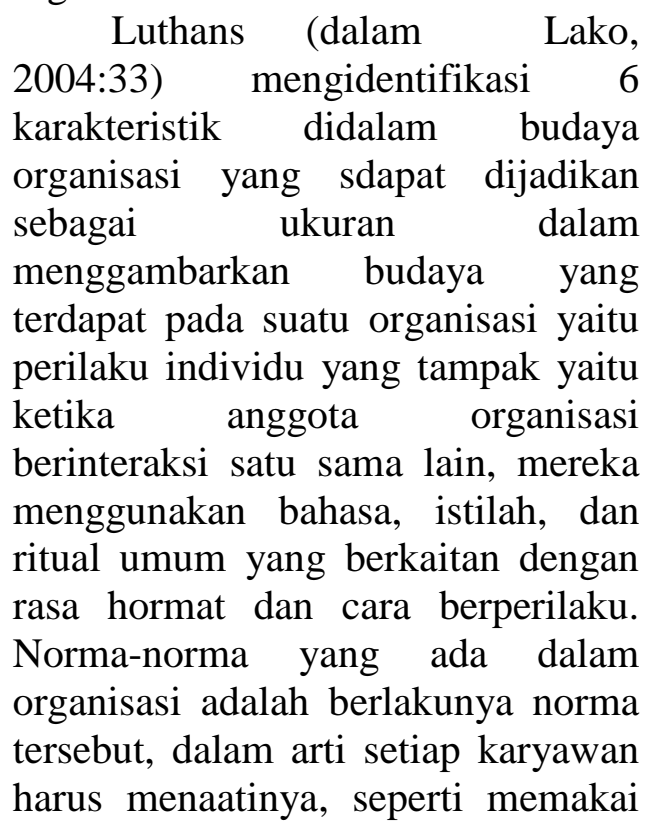

pakaian kerja, karyawan harus absen ketika datang dan pulang kerja, memakai tanda pengenal kerja. Nilainilai yang dominan dalam kehidupan organisasi adalah nilai- nilai yang disepakati dan tertanam dalam suatu lingkup organisasi yang mengakar pada suatu kebiasaan seperti melakukan briefing agar pekerjaan dapat terencana dengan baik, mengadakan pertemuan khusus untuk evaluasi.

Peraturan yang berlaku adalah aturan-aturan yang tegas dari organisasi. Seperti karyawan harus mempelajari peraturan ini agar keberadaanya dapat diterima dalam organisasi. Iklim organisasi seperti cara para anggota organisasi berinteraksi dengan rekan kerja seperti atasan, bawahan dan antar karyawan. Pada dasarnya seorang karyawan dalam melaksanakan dan menyelesaikan tugas yang dibebankan kepadanya diharapkan untuk dapat menunjukkan suatu kinerja terbaik yang bisa ditunjukkan oleh karyawan tersebut.

Menurut Mangkunegara (2009:67) kinerja adalah hasil kerja secara kualitas dan kuantitas yang dicapai oleh seseorang karyawan dalam melaksanakan tugasnya sesuai dengan tanggungjawab yang diberikan kepadanya. Mangkunegara (2009:67) kinerja karyawan dapat dinilai dari kualitas kerja yaitu menunjukan kerapihan, ketelitian, keterkaitan hasil kerja dengan tidak mengabaikan volume pekerjaan. Kuantitas kerja yaitu menunjukan banyaknya jumlah jenis pekerjaan yang dilakukan dalam suatu waktu sehingga efisiensi dan efektivitas dapat terlaksana sesuai dengan tujuan perusahaan. Tanggungjawab 
yaitu menunjukan seberapa besar karyawan dalam menerima dan melaksanakan pekerjaannya, mempertanggungjawabkan hasil kerja serta sarana dan prasarana yang digunakan dan perilaku kerjanya setiap hari. Kerja sama yaitu mampu menjalin hubungan kerja baik pada unit kerjanya atau dengan unit kerja lainnya. Inisiatif yaitu dengan adanya inisiatif dari dalam diri anggota organisasi untuk melakukan pekerjaan serta mengatasi masalah dalam pekerjaan tanpa menunggu perintah. Berdasarkan pada teori yang telah di kemukan mengenai budaya organisasi berpengaruh terhadap kinerja karyawan dengan lingkungan kerja sebagai variabel moderasi diatas, dapat digambarkan sebuah model kerangka berfikir sebagai berikut :

Gambar 1. Kerangka Pikir Penelitian

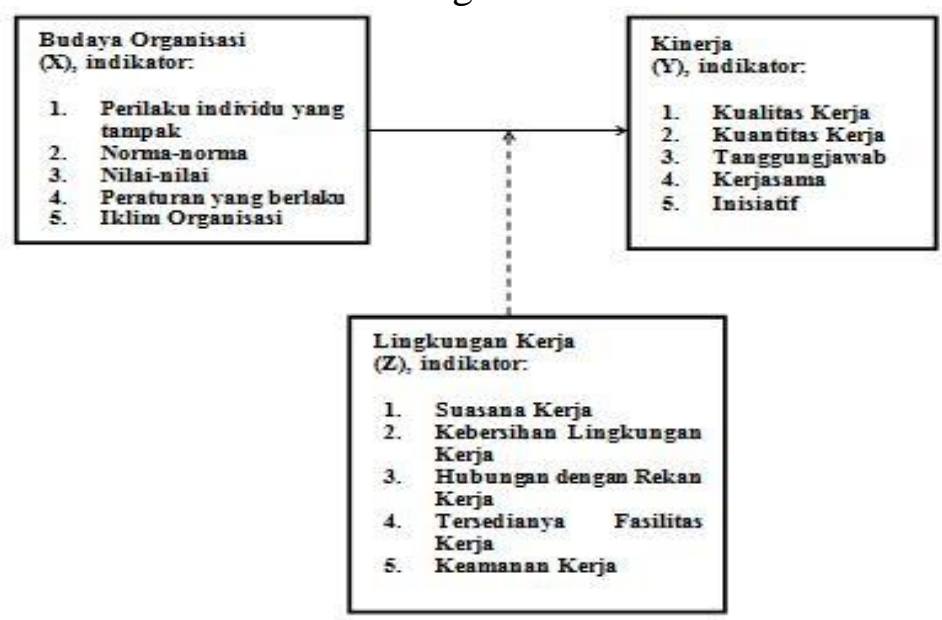

Berdasarkan landasan teori diatas, dapat disusun hipotesis penelitian sebagai berikut:

$\mathrm{H}_{1}$ : Diduga budaya organisasi berpengaruh positif dan signifikan terhadap kinerja karyawan dengan lingkungan kerja sebagai variabel moderasi.

\section{METODE PENELITIAN}

Penelitian ini dilaksanakan pada Balai Penelitian Tanaman Pemanis dan Serat. Balittas terletak di Jln. Raya Karangploso, 199 Malang. Jenis penelitian yang dilakukan adalah penelitian survey, dimana peneliti melakukan wawancara dalam pengumpulan data. Menurut (Singarimbun, 2001), penelitian survey adalah penelitian yang mengambil sampel dari satu populasi dan menggunakan kuisioner sebagai alat pengumpulan data yang pokok. Populasi adalah wilayah generalisasi yang terdiri atas obyek atau subyek yang mempunyai kuantitas dan karakteristik tertentu yang diterapkan oleh peneliti untuk dipelajari dan kemudian ditarik kesimpulan (Sugiyono, 2002:57). Populasi dalam penelitian ini adalah tenaga administrasi Balai Penelitian Tanaman Tembakau dan Serat (kepegawaian, keuangan, rumah tangga dan perlengkapan) sejumlah 40 orang.

Teknik pengambilan sampel dalam penelitian ini adalah dengan 
menggunakan teknik total sampling. Digunakan teknik ini karena populasi yang akan diteliti kurang dari 100 orang sehingga sampel yang diambil berasal dari keseluruhan populasi yang ada dalam Balittas yang berjumlah 40 orang.

Teknik pengumpulan data yang dilakukan dengan mengajukan lembaran angket yang berisi daftar pertanyaan kepada responden atau karyawan Balittas malang. Interval pertanyaan dalam angket ini adalah 1-5 dengan pernyataan Sangat Tidak Setuju (STS) hingga Sangat Setuju (SS). Teknik pengukuran variabel dengan menggunakan skala likert untuk memberikan nilai terhadap jawaban responden.

Menurut Sugiyono (2001) skala likert digunakan untuk mengukur sikap, pendapat dan persepsi seseorang atau sekelompok orang tentang fenomena sosial. Dalam penelitian fenomena sosial ini telah ditetapkan secara spesifik oleh peneliti, yang selanjutnya disebut sebagai variable penelitian. Skala pengukuran atas jawaban dari hasil pernyataan dengan menggunakan skala likert. Definisi operasional variabel merupakan petunjuk tentang bagaimana suatu variabel di ukur, sehingga peneliti dapat mengetahui baik buruknya pengukuran tersebut.

\section{HASIL PENELITIAN DAN PEMBAHASAN}

Dari hasil uji validitas dapat diketahui bahwa masing-masing indikator yang digunakan mempunyai nilai $r_{\text {hitung }}$ yang lebih besar dari $r_{\text {tabel }}$. Hal ini berarti item dalam pertanyaan yang digunakan dalam penelitian ini layak atau valid digunakan sebagai pengumpul data.

Pengujian reliabilitas dalam penelitian ini diketahui bahwa nilai dari alpha cronbach untuk semua variabel > 0,6. Karena nilai alpha cronbach lebih besar dari 0,6. maka dapat dinyatakan bahwa item pertanyaan yang digunakan untuk penelitian ini sudah reliabel. Normalitas adalah syarat yang harus dipenuhi oleh suatu sebaran data sebelum melakukan analisis. Hasil Output dari pengujian normalitas dengan Kolmogrof-Smirnov adalah sebagai berikut:

Tabel 1. Uji Normalitas Variabel

\begin{tabular}{llr}
\hline & & Unstandardized Residual \\
\hline $\mathrm{N}$ & & 41 \\
Normal Parameters & Mean & .0000000 \\
& Std. Deviation & 1.21805391 \\
Most Extreme Differences & Absolute & .069 \\
& Positive & .056 \\
& Negative &,- 069 \\
Kolmogorov-Smirnov Z & & .441 \\
Asymp. Sig. (2 tailed) & & .990 \\
\hline
\end{tabular}


Tabel 2. Hasil Rentang Budaya Organisasi

\begin{tabular}{|c|c|c|c|c|c|c|c|}
\hline \multirow{2}{*}{ Item } & \multicolumn{5}{|c|}{ Skor Jawaban Responden } & \multirow{2}{*}{$\begin{array}{c}\text { Skor Rentang } \\
\text { Skala }\end{array}$} & \multirow{2}{*}{ Keterangan } \\
\hline & SS & $\mathrm{S}$ & $\mathrm{N}$ & TS & STS & & \\
\hline $\mathrm{X} 1.1$ & 21 & 17 & 2 & 0 & 0 & 176 & Sangat Kuat \\
\hline $\mathrm{X} 2.2$ & 27 & 12 & 1 & 0 & 0 & 186 & Sangat Kuat \\
\hline X3.3 & 23 & 17 & 0 & 0 & 0 & 183 & Sangat Kuat \\
\hline $\mathrm{X} 4.4$ & 2 & 20 & 13 & 3 & 0 & 135 & Cukup Kuat \\
\hline $\mathrm{X} 5.5$ & 5 & 21 & 9 & 5 & 0 & 140 & Kuat \\
\hline Total & & & & & & 823 & \\
\hline Rata-rata & & & & & & 165 & Kuat \\
\hline
\end{tabular}

Berdasarkan Tabel 2 dapat dikatakan bahwa rata - rata budaya organisasi yang dimiliki oleh karyawan pada Balai Penelitian Tanaman Pemanis dan Serat Malang kuat, dari kategorisasi di atas dapat diketahui bahwa budaya organisasi berpengaruh terhadap kinerja karyawan pada Balai Penelitian Tanaman Pemanis dan Serat Malang.
Jadi disini ketika suatu budaya organisasi itu kuat dalam artian budaya organisasi yang mengacu pada reward atau punishment di suatu perusahaan itu kuat, hal tersebut bisa menjadi suatu senjata yang ampuh dalam meningkatkan kinerja karyawan dalam memajukan perusahaannya.

Tabel 3. Hasil Rentang Skala Lingkungan Kerja

\begin{tabular}{|c|c|c|c|c|c|c|c|}
\hline \multirow{2}{*}{ Item } & \multicolumn{5}{|c|}{ Skor Jawaban Responden } & \multirow{2}{*}{$\begin{array}{c}\text { Skor Rentang } \\
\text { Skala }\end{array}$} & \multirow{2}{*}{ Keterangan } \\
\hline & SS & $\mathrm{S}$ & $\mathrm{N}$ & $\mathrm{TS}$ & STS & & \\
\hline Z1.1 & 6 & 22 & 8 & 4 & 0 & 150 & Kondusif \\
\hline $\mathrm{Z} 2.2$ & 14 & 22 & 3 & 1 & 0 & 169 & Sangat Kondusif \\
\hline $\mathrm{Z} 3.3$ & 13 & 26 & 1 & 0 & 0 & 172 & Sangat Kondusif \\
\hline Z4.4 & 3 & 29 & 5 & 3 & 0 & 152 & Kondusif \\
\hline Z5.5 & 2 & 20 & 13 & 3 & 0 & 135 & Cukup Kondusif \\
\hline Total & & & & & & 778 & \\
\hline Rata-rata & & & & & & 156 & Kondusif \\
\hline
\end{tabular}

Berdasarkan Tabel 3 dapat dikatakan bahwa lingkungan kerja bisa di katakan kondusif. Dari hasil pengkategorisasian di atas dapat di ketahui bahwa lingkungan kerja memiliki pengaruh dalam menentukan kinerja suatu karyawan pada Balittas Malang. Dalam suatu perusahaan, lingkungan kerja memiliki pengaruh besar di dalam suatu perusahaan, karena dengan lingkungan kerja yang baik para karyawan bisa mendapatkan kenyamanan tersendiri dalam mengerjakan tugas yang diberikan sehingga pekerjaan tersebut cepat terselesaikan dengan hasil yang maksimal pula. 
Tabel 4. Hasil Rentang Skala Kinerja

\begin{tabular}{|c|c|c|c|c|c|c|c|}
\hline \multirow{2}{*}{ Item } & \multicolumn{5}{|c|}{ Skor Jawaban Responden } & \multirow{2}{*}{$\begin{array}{c}\text { Skor Rentang } \\
\text { Skala }\end{array}$} & \multirow{2}{*}{ Keterangan } \\
\hline & SS & $\mathrm{S}$ & $\mathrm{N}$ & TS & STS & & \\
\hline Y1.1 & 27 & 13 & 0 & 0 & 0 & 187 & Sangat Tinggi \\
\hline Y2.2 & 2 & 20 & 13 & 3 & 0 & 135 & Cukup Tinggi \\
\hline Y3.3 & 11 & 25 & 2 & 2 & 0 & 165 & Tinggi \\
\hline Y4.4 & 5 & 30 & 3 & 2 & 0 & 158 & Tinggi \\
\hline Y5.5 & 25 & 15 & 0 & 0 & 0 & 185 & Sangat Tinggi \\
\hline Total & & & & & & 827 & \\
\hline Rata-rata & & & & & & 165 & Tinggi \\
\hline
\end{tabular}

Berdasarkan Tabel 4 dapat dikatakan bahwa rata - rata kinerja karyawan pada Balai Penelitian Tanaman Pemanis dan Serat Malang bisa di katakan tinggi, hal ini membuktikan bahwa tingkat antusiasme karyawan pada Balai Penelitian Tanaman Pemanis dan Serat Malang dalam menyelesaikan pekerjaannya lumayan baik dari hasil jawaban dari kuisioner.
Berdasarkan hasil analisis yang telah dilakukan, dapat disajikan hasil Moderated Regression Analysis (MRA) yang digunakan untuk mengetahui pengaruh lingkungan kerja memoderasi signifikansi pengaruh budaya organisasi terhadap kinerja karyawan Balai Penelitian Tanaman Pemanis dan Serat Malang yang secara lengkap dapat diuraikan pada tabel berikut:

Tabel 5. Hasil MRA

\begin{tabular}{lcccc}
\hline $\begin{array}{c}\text { Variabel } \\
\text { Terikat }\end{array}$ & $\begin{array}{c}\text { Variabel Bebas \& } \\
\text { Moderasi }\end{array}$ & $\begin{array}{c}\text { Unstandarized } \\
\text { Coefficients }\end{array}$ & $\mathrm{T}_{\text {hitung }}$ & Sig. \\
\hline Kinerja & Budaya Organisasi & 1,954 & 2,097 & 0,043 \\
& $\begin{array}{c}\text { Lingkungan Kerja } \\
\text { Moderasi (X*Z) }\end{array}$ & 2,093 & 2,224 & 0,032 \\
Konstanta & & $-0,080$ & $-1,744$ & 0,089 \\
$\mathrm{R}$ & $:-27,809$ & & \\
R square & $: 0,783$ & & \\
Adjusted R square & $: 0,612$ & & \\
$\mathrm{~F}$ & $: 0,581$ & & \\
Probabilitas & 19,488 & & \\
\hline
\end{tabular}

Berdasarkan pada Tabel 5 didapatkan persamaan regresi sebagai berikut: $\mathrm{Y}=-27,809+1,954$ $\mathrm{XI}+2,093 \mathrm{X} 2-0,080 \mathrm{X} 1 * \mathrm{X} 2+\varepsilon$

Berdasarkan analisis pada Tabel 5 diperoleh hasil $\mathrm{R}^{2}$ (koefisien determinasi) sebesar 0,612. Hal ini menunjukan keragaman (kinerja) dapat dijelaskan oleh variabel budaya organisasi, lingkungan kerja dan moderasi yaitu sebesar 0,612. Dengan kata lain, kontribusi budaya organisasi, lingkungan kerja dan moderasi terhadap kinerja sebesar $61,2 \%$, sedangkan sisanya sebesar $38,8 \%$ merupakan kontribusi variabel lain yang tidak dibahas disini. 
Tabel 6. Hasil Uji F (simultan)

\begin{tabular}{cccc}
\hline Nilai $\mathrm{F}_{\text {hitung }}$ & ${\text { Nilai } \mathrm{F}_{\text {tabel }}}$ & Sig. & Keterangan \\
\hline 19,488 & 3,25 & 0,000 & H1 Diterima \\
\hline
\end{tabular}

Pada tabel 6 didapatkan $\mathrm{F}_{\text {hitung }}$ sebesar 19,488 dengan tingkat signifikansi sebesar 0,000. Dari perhitungan $F_{\text {tabel }}$ yang sudah dilakukan, didapatkan nilai $\mathrm{F}_{\text {tabel }}$ sebesar 3,25 yang nilainya lebih kecil daripada $F_{\text {hitung }}$ yang berarti menerima hipotesis yang diajukan dalam penelitian ini yaitu lingkungan kerja memoderasi pengaruh budaya organisasi terhadap kinerja karyawan pada Balai Penelitian Tanaman Pemanis dan Serat Malang.

Tabel 7. Hasil Uji T (parsial)

\begin{tabular}{ccccc}
\hline Variabel & Nilai $\mathrm{F}_{\text {hitung }}$ & Nilai $\mathrm{F}_{\text {tabel }}$ & Sig. & Keterangan \\
\hline Budaya Organisasi & 2,097 & 2,026 & 0,043 & H1 Diterima \\
Lingkungan Kerja & 2,224 & 2,026 & 0,032 & H1 Diterima \\
Moderasi $\left(\mathrm{X}^{*} \mathrm{Z}\right)$ & $-1,744$ & 2,026 & 0,089 & H1 Diterima \\
\hline
\end{tabular}

Dari uraian hasil $\mathrm{t}_{\text {hitung }}$ dan $\mathrm{t}_{\text {tabel }}$ pada tabel 7 maka lingkungan kerja (Z) memoderasi pengaruh signifikan budaya organisasi (X) terhadap kinerja (Y) dari hasil perhitungan parsial menunjukkan bahwa pada taraf nyata $5 \%(\mathrm{a}=0,05)$ diperoleh nilai $t_{\text {tabel }}$ sebesar $-2,021$ karena nilai $\mathrm{t}_{\text {hitung }}>\mathrm{t}$ tabel $(-1,744>-$ 2,021), maka dapat disimpulkan bahwa secara parsial variabel lingkungan kerja (Z) memoderasi pengaruh budaya organisasi (X) terhadap kinerja (Y). Jadi hipotesis ke-1 $\left(\mathrm{H}_{1}\right)$ dikatakan bahwa lingkungan kerja memoderasi pengaruh signifikan budaya organisasi terhadap kinerja karyawan dapat diterima.

Tingkat budaya organisasi pada Balittas Malang memiliki skor rentang skala rata-rata sebesar 165 yang masuk dalam rentang skala dengan kriteria kuat. Hal ini menunjukkan bahwa, karyawan yang ada pada Balai Penelitian Tanaman Pemanis dan Serat Malang masingmasing memiliki budaya organisasi yang kuat selama di perusahaan. Dalam hal ini tentu saja budaya organisasi berperan sebagai penunjang kinerja seorang karyawan dalam menyelesaikan pekerjaan yang ada. Hasil penelitian ini diperkuat oleh (Chatman Jennnifer dan Bersade, 1997) yang menyatakan budaya organisasi yang kuat membantu kinerja organisasi karena menciptakan suatu tingkatan yang luar biasa dalam diri karyawan.

Kinerja karyawan di Balai Penelitian Tanaman Pemanis dan Serat Malang memliki skor rentang skala rata-rata sebesar 165 yang masuk dalam rentang skala dengan kriteria tinggi. Hal ini menunjukkan bahwa hal ini bahwa tingkat antusiasme karyawan pada Balai Penelitian Tanaman Pemanis dan Serat Malang dalam menyelesaikan pekerjaannya baik hal tersebut dapat diketahui dari hampir seluruh responden mampu mencapai kuantitas pekerjaan dan meningkatkan hasil kerja yang dicapai dalam perusahaan. 
Keadaan ini dibuktikan dengan karyawan yang memberikan konstribusi kepada tim atau rekan kerja lain dan mampu bekerja sama dengan setiap rekan kerja serta mampu meminimalisir jumlah kesalahan yang terjadi di perusahaan.

Lingkungan kerja yang ada di Balai penelitian Tanaman Pemanis dan Serat Malang memiliki skor rentang skala rata-rata sebesar 156 yang masuk dalam rentang skala dengan kriteria kondusif. Di dalam suatu perusahaan, lingkungan kerja memiliki pengaruh yang bisa dikatakan besar di dalam suatu perusahaan, karena dengan lingkungan kerja yang baik para karyawan bisa mendapatkan kenyamanan tersendiri dalam mengerjakan tugas yang diberikan sehingga pekerjaan tersebut cepat terselesaikan dengan hasil yang maksimal pula.

Hasil perhitungan MRA menunjukan bahwa, lingkungan kerja dapat memoderasi pengaruh signifikan budaya organisasi terhadap kinerja karyawan Balai penelitian Tanaman Pemanis dan Serat Malang. Hal ini diperkuat dengan hasil pengujian hipotesis secara simultan dan parsial yang menyatakan hipotesis yang diajukan dapat diterima secara simultan dan parsial. Hal ini dapat dijelaskan, ketika karyawan memiliki budaya organisasi yang kuat, maka akan berdampak terhadap peningkatan kinerja karyawan.

Dilihat dari koefisien determinasi untuk model regresi MRA sebesar 0,612, nilai ini mengindikasikan sebesar $61,2 \%$ variasi dari kinerja dapat dijelaskan oleh variabel budaya organisasi, lingkungan kerja dan moderasi (interaksi antara budaya organisasi dan lingkungan kerja).

Hal ini dapat diinterpretasikan bahwa, walaupun lingkungan kerja secara sendiri mempunyai pengaruh positif terhadap kinerja, namun jika diinteraksikan dengan budaya organisasi variabel lingkungan kerja justru mengurangi pengaruh budaya organisasi terhadap kinerja karena nilai koefesien regresi moderasi bersifat ( - ) negatif.

\section{SIMPULAN}

Berdasarkan hasil penelitian yang telah dilakukan, dapat disimpulkan hal-hal sebagai berikut: Budaya Organisasi (X) pada Balai Penelitian Tanaman Pemanis dan Serat Malang termasuk dalam kriteria kuat, kinerja karyawan (Y) di Balai Penelitian Tanaman Pemanis dan Serat Malang termasuk dalam tinggi dan lingkungan kerja (Z) karyawan di Balai Penelitian Tanaman Pemanis dan Serat Malang termasuk dalam kriteria kondusif.Lingkungan kerja (Z) dapat memoderasi pengaruh signifikan budaya organisasi (X) terhadap kinerja karyawan (Y) Balai Penelitian Tanaman Pemanis dan Serat Malang.

\section{DAFTAR PUSTAKA}

Arikunto, Suharsimi. 2006. Prosedur Penelitian Suatu Pendekatan Praktek. Jakarta: Rineka Cipta

Crissida, Hery. 2013. Pengaruh Budaya Organisasi, Lingkungan Kerja Fisik, dan Disiplin Kerja Terhadap Kinerja (Studi pada karyawan PT. SUMMIT OTO Finance Cabang Jember). 
Ghoniyah, Nunung dan Masurip. 2011. "Peningkatan Kinerja Karyawan Melalui

Kepemimpinan, Lingkungan Kerja dan Komitmen". Jurnal Dinamika Manajemen. Vol. 2. No. 2. 2011, Hal. 118 - 129. Universitas Islam Sultan Agung. Semarang.

Ghozali, Imam. 2013. Aplikasi Analisis Multivariate dengan Program SPSS. Edisi Ketujuh. Semarang : Badan Penerbit Undip.

Gibson. 1997. Manajemen Sumber Daya Manusia. Jakarta : Bumi Aksara.

Hasibuan, Malayu. 2001. Manajemen Dasar, Manajemen Sumber Daya Manusia. Jakarta : Bumi Aksara.

Kharisma, Gogy Bara. 2013. Pengaruh Budaya Organisasi dan Lingkungan Kerja Terhadap Kinerja (Studi pada karyawan Koperasi Serba Usaha Setya Usaha di Kabupaten Jepara). Skripsi dipublikasi Universitas Negeri Semarang.

Leblebici, Demet. 2012."Impact of Work Place Quality on Employee's Productivity:Case Study of Bank in Turkey". Dalam Journal of Business, Economics \& Finance. Okan University, Turkey.

Luthans, Fred, 1997. Organizational Behavior, Third Edition. The McGraw-Hill Companies Inc., New York.

Mangkunegara, Anwar. P. 2002. Manajemen Sumber Daya
Manusia Perusahaan.

Bandung : Rosda Karya.

Mathis, Robert L. dan Jackson John H. 2002. Manajemen Sumber Daya Manusia. Jakarta: Salemba Empat.

Nitisemito, Alex. 1992. Manajemen Personalia : Manajemen Sumber Daya Manusia. Jakarta: Ghalia Indonesia.

Ojo, Olu. 2010.”Organisational Culture and Corporate Performance: Empirical Evidence from Nigeria". Dalam Journal of Business, Governance and Ethics. Osun State University, Nigeria

Prawirosentono, Suyadi. 1992. Kebijakan Kinerja Karyawan Edisi Pertama. Yogyakarta : BPFE.

Rivai, V., \& Mulyadi, D. (2012). Kepemimpinan dan Perilaku Organisasi. Jakarta: Rajawali Pers.

Robbins, Stephen.P. 2002. PrinsipPrinsip Perilaku Organisasi. Jakarta: Erlangga.

Sakaran, U. 2003. Reaserch Methodhs for Buisness. USA: John Willey and Sons Inc.

Sedarmayanti. 2001. SDM dan Produktivitas Kerja. Bandung: Mandar Maju

Siagian, Prof DrSondang P. 2002. Manajemen Sumber Daya Manusia. Yogyakarta : PT. Bina Aksara.

Sugiyono. 2010. Metode Penelitian Kuantitatif Kualitatif dan $R \& D$. Bandung: Alfabeta

Tika, Prabundu H,Moh. 2006. Budaya Organisasi dan Peningkatan Kinerja.Jakarta: PT Bumi Aksara 